\title{
DEVELOPMENT OF LOGO DESIGN FOR COFFEE SHOP “KONTAK POINT” IN CIBINONG, BOGOR DISTRICT
}

\author{
Kania RATNASARI", Levyda LEVYDA \\ Faculty of Economic and Business, Universitas Sahid Jakarta \\ *niotfemale@gmail.com
}

\begin{abstract}
Coffee shops in the end became a very promising business. One of the coffee shop entrepreneurs who entered the beverage sector industry was Pijar Panggalih where the coffee shop was named Kontak Point. The coffee shop is located in the Cibinong area, Bogor Regency. There are several problems that happened to this coffee shop such as the lack of partner understanding of the importance of an attractive and informative logo design as well as the importance of registering a trademark/business and also the partner do not have an attractive and informative business logo. The purpose of this activity program is to provide socialization and assistance for Kontak Point coffee shop, especially related to understanding the importance of an attractive product logo design and how to develop it. The implementation of this socialization and mentoring activity will be carried out in stages where the place for the implementation of this activity will be directly carried out at the partner's coffee shop. The method and implementation pattern that will be used in this outreach and mentoring activity is the lecture method, question and answer, discussion, tutorial and consultation. The output of this PKM activity is a change in the logo design that will be used by Partners.
\end{abstract}

Keywords: Kontak Point, Coffee Shop, UMKM, Entrepreneur, Entrepreneurship

\section{BACKGROUND}

Coffee is one of the local drinks of Indonesian people who are in demand from all walks of life which have each characteristic taste. The tradition of drinking coffee in coffee shops has become a habit of Indonesian society where consumers who come to a coffee shop do not just drink coffee, but also have become the destination of certain activities such as meeting with friends or work partners, as a place for socialization, and or as a place of learning for students and college students (Widodo, 2014). Coffee shops in the end became a very promising business. The forms of business are very diverse, ranging from exclusive and modern coffee shops to standard and traditional coffee shops. In fact, there are lots of coffee shops that pop up from small alleys, highways, hidden or strategic places, to shopping centers such as malls (Solikatun et al., 2015).

Consumer needs and desires for food and beverages, practical things, and consumptive attitudes have led to the emergence and development of many coffee shops that are able to provide these needs and desires practically (Ompusunggu \& Djawahir, 2014). To meet these needs and desires, MSME actors in Indonesia can see this promising and potential business opportunity with the emergence of many coffee shops or coffeeshops in Indonesia. Coffee commodity in Indonesia is one of the supporting commodities for the Indonesian economy. The main factor is that Indonesia is one of the largest coffee bean producing and exporting countries in the world (Said, 2017). Not only in big cities like Jakarta, there are also many coffee shops around Jakarta, to be precise, namely Cibinong, where Cibinong is the capital of Bogor Regency, so of course coffee shops are a very promising business. The tight competition of existing coffee shops makes MSMEs in coffee shops increasingly demanded to move faster in terms of attracting consumers, so that MSMEs must always be able to provide satisfaction to their consumers by attracting consumers to come to visit. The increasing demand for coffee drinks and the growing trend of drinking coffee in the Cibinong area have made more and more entrepreneurs try to enter the coffee shop industry.

One of the coffee shop entrepreneurs who entered the beverage sector industry was Pijar Panggalih where the coffee shop was named Kontak Point. The coffee shop is located in the Cibinong area, Bogor Regency and only opened on February 17, 2020. Kontak Point is a brand that was taken by the owner of the coffee shop because of his love for everything related to automotive and motorcycles, so the word "contact" became the choice. Then the word "Point" itself was chosen in the hope that many consumers would come to visit his coffee shop to carry out various activities so that the coffee shop became the meeting point. There are still some shortcomings regarding the business concept of the "Kontak Point" coffee shop, one of which is the logo form which is very simple and uninformative so that consumers who come don't even realize that it is the logo of the "Kontak Point" coffee shop. The following is a description of Pijar Panggalih's Kontak Point, as follows:

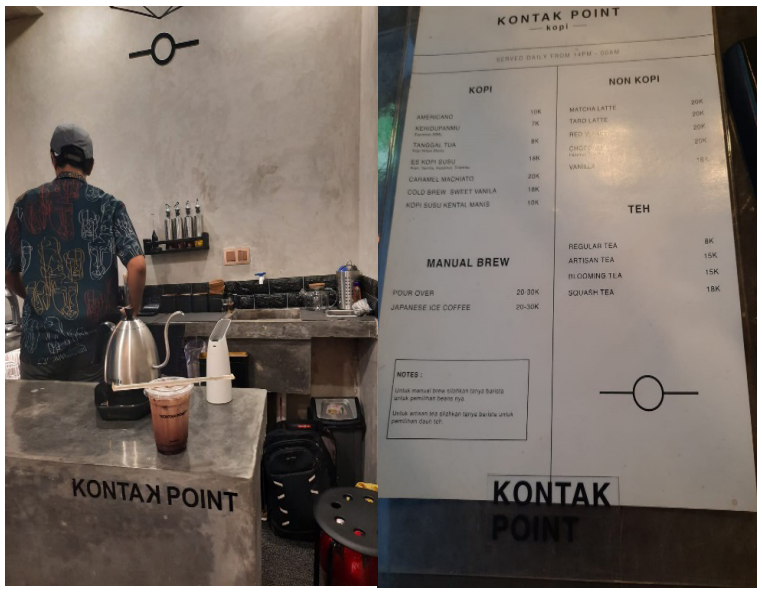

Figure 1. Coffee Shop "Kontak Point" 


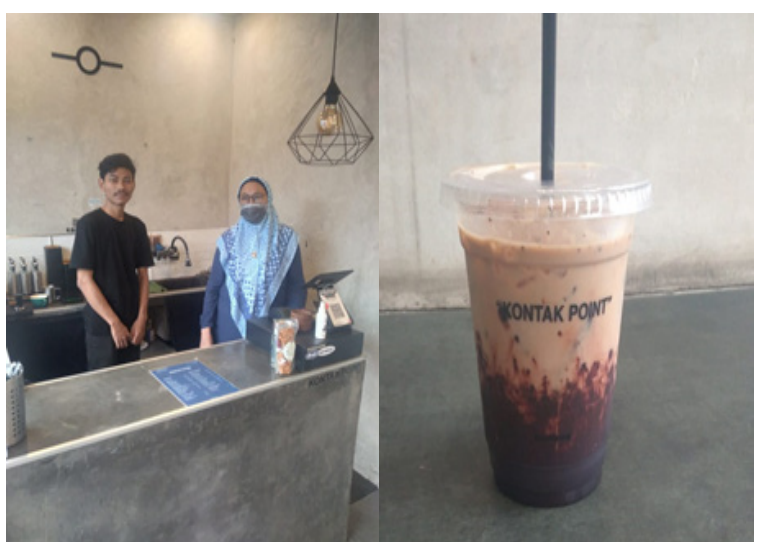

Figure 2. Coffee of "Kontak Point" and with the owner

\section{Identification of Problems}

Brand is one of the most important parts of a product. A brand can be an added value for a product, whether it is a product in the form of goods or services, which will differentiate the product from other products (Budiman \& Ifrani, 2019). This added value is very profitable for producers or companies, that's why many companies try to continue to introduce their brands from time to time, especially to consumers who are their target market.

The results of observations made by Partners together with the Team in mapping the problem are as follows:

1. The first problem is the lack of partner understanding of the importance of an attractive and informative logo design as well as the importance of registering a trademark/business

2. The second problem is that partners do not have an attractive and informative business logo.

It can be seen in Figure 1 that the logo owned by the coffee shop owner is still simple, unattractive and uninformative. This is considered to need to be responded to and anticipated as an effort to strengthen the competitiveness of the Kontak Point coffee shop. The solutions that we will provide to Partners in this community service activity are in the form of socializing as well as re-designing business logos and providing assistance for making business logo designs as follows:

1. Providing socialization and counseling about the importance of having an attractive and informative business logo design

2. Assistance in making attractive and informative business logo re-designs.

\section{METHOD}

Based on the problems that have been described previously and the agreement between the proposing team and partners, the solutions offered to overcome the existing problems can be done using the following approach methods:

1. Lecture, discussion, and question and answer methods are used to convey information about product/business brands and attractive business logo designs
2. Consultative mentoring/workshop methods on the creation, re-design and or improvement of business logos.

\section{RESULTS AND DISCUSSION}

To implement the implementation method, the stages of implementation activities are carried out with the following steps:

\section{Problem Deepening.}

This activity collects data, facts, and information related to the conditions and problems of partners, namely regarding logo design and business legality. The following is an example of an initial logo from a partner that was deemed unattractive and uninformative.

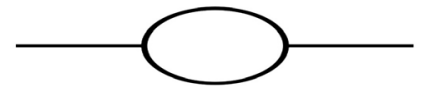

\section{Figure 3. Partner Initial Logo (old)}

Based on Figure 2 above is the initial logo of the partner, to redesign the logo without changing the meaning and impression that the partner wants to create, we provide several solutions in the form of new designs where one of the logo designs will be chosen by our partner.

\section{Socialization.}

The aspect studied in this activity is to provide information regarding the importance of an attractive and informative logo design. The socialization was carried out by the PKM team to partners 2 times. The first activity was filled with material about the importance of the brand and logo of a business with the resource person, Kania Ratnasari. The location is held at the coffee shop "Kontak Point". The second activity was filled with material on how to design an attractive and informative logo design with assistance in making attractive logo designs with resource persons, namely Dr. Levyda. The materials that we convey to partners are as follows:

\section{Table 1. Community Service Program Material}

\begin{tabular}{|c|c|c|}
\hline No & Presenter & Program Material \\
\hline 1 & $\begin{array}{l}\text { Kania Ratnasari, } \\
\text { ST., MIB }\end{array}$ & $\begin{array}{l}\text { - Reasons for the importance of a } \\
\text { business must have an attractive } \\
\text { and informative logo } \\
\text { - An introduction to the meaning, } \\
\text { benefits, and purpose of a logo } \\
\text { created } \\
\text { - Important aspects to understand } \\
\text { before creating a logo } \\
\text { - The procedure for making a good } \\
\text { and correct logo }\end{array}$ \\
\hline 2 & $\begin{array}{l}\text { Dr. Levyda, SE., } \\
\text { MM }\end{array}$ & $\begin{array}{l}\text { - Mentoring and practice of logo } \\
\text { redesign }\end{array}$ \\
\hline
\end{tabular}

The provision of material that we have conveyed is expected to provide increased knowledge and understanding which can then be applied by partners in business activities. 


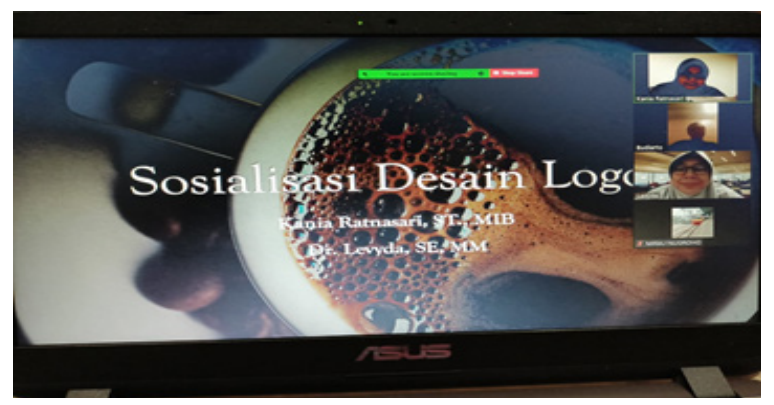

Figure 4. Socialization with partner (1)

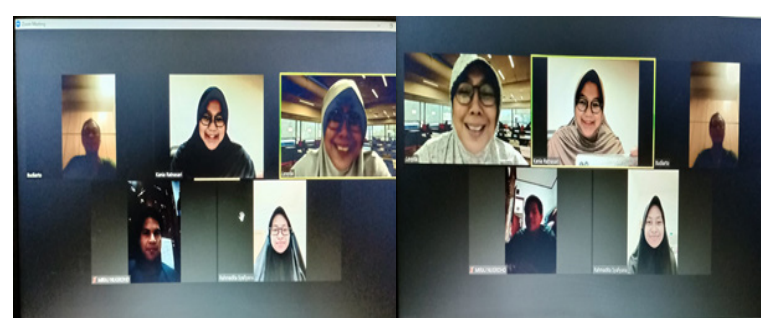

Figure 5. Socialization with partner (2)

\section{Implementation.}

In the first stage, what we do with partners is making, re-designing and or improving the business logo. The logos that we have designed are as follows:

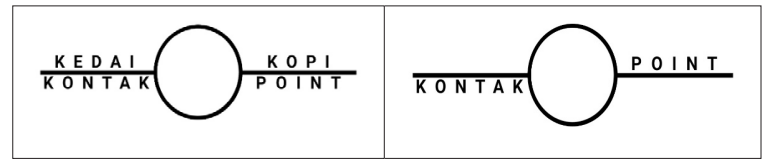

Figure 6. Re-design of Partner Logo (1)

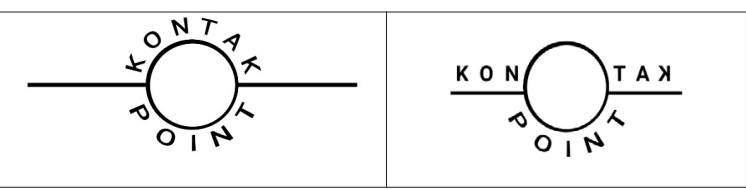

Figure 7. Re-design of Partner Logo (2)

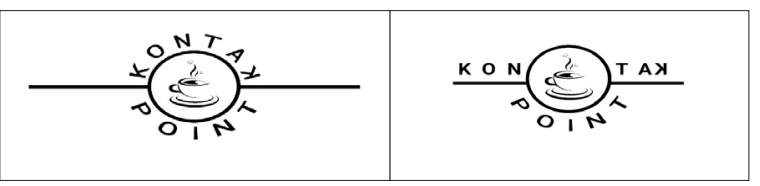

Figure 8. Re-design of Partner Logo

From several logos that we have designed, then we present them to partners and ask partners to choose which logo design they like without changing the meaning and impression of the logo itself. Finally, partners choose designs according to their interests, which are as follows:

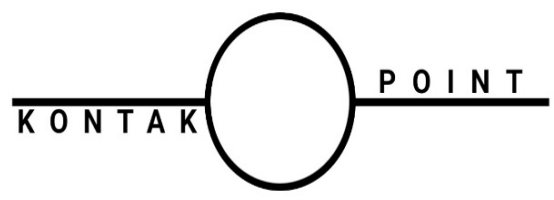

Figure 9. New Design of Partner Logo
The choice of logo design was because partners did not want to change the meaning and impression of the previous logo design, only to make it more interesting and informative, we added the partner's coffee business brand name so that consumers easily remember it, not only the logo but also the business brand Here is the change from the old logo design to the new logo design.
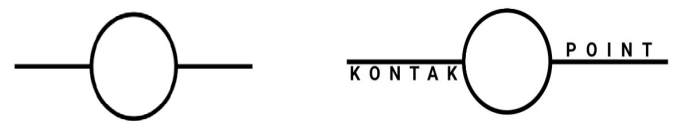

Figure 10. The changing of the old logo design to the new logo design

\section{CONCLUSION}

Partners still lack knowledge about attractive and informative logo designs in terms of business brand aspects, so the PKM team conducts socialization by providing related materials and assisting partners from starting to create various new logo designs. The logo that has been chosen by the partner will continue to use the logo.

\section{ACKNOWLEDGEMENT}

This community service is an outcome of an internal grant and is funded by the Institute for Research and Community Service, Sahid University. The author would like to thank Prof Giyatmi as the head of the Institute for Research and Community Service, Sahid University.

\section{REFERENCES}

Budiman, R., \& Ifrani, I. (2019). sasirangan dalam rangka perlindungan hak kekayaan. 1, 98-103.

Ompusunggu, M. P., \& Djawahir, A. H. (2014). Gaya Hidup dan Fenomena Perilaku Konsumen pada Warung Kopi di Malang. Jurnal Aplikasi Manajemen, 12(2), 188-196.

Said, I. (2017). Warung Kopi Dan Gaya Hidup Modern. Jurnal Al-Khitabah, III(1), 33-47.

Solikatun, S., Kartono, D. T., \& Demartoto, A. (2015). Perilaku Konsumsi Kopi Sebagai Budaya Masyarakat Konsumsi (Studi Fenomenologi Pada Peminum Kopi Di Kedai Kopi Kota Semarang). Jurnal Analisa Sosiologi, 4(1), 60-74.

Widodo, A. J. (2014). Analisis Preferensi Pengunjung Kedai Kopi Terhadap Menu Kedai Kopi di Kota Semarang ( Studi kasus: 4 kedai kopi di Kota Semarang ). In Ekonomika, Fakultas Bisnis, D AN Diponegoro, Universitas. 